\title{
A SPATIAL ANALYSIS ON GIS-HEDONIC PRICING MODEL ON THE INFLUENCE OF PUBLIC OPEN SPACE AND HOUSE PRICE IN KLANG VALLEY, MALAYSIA
}

\author{
A. MZainora ${ }^{\text {a }} *$, M. N. Norzailawati ${ }^{\text {a }}$, P. Tuminah ${ }^{a}$ \\ ${ }^{a}$ Kulliyyah of Architecture and Environmental Design, International Islamic University Malaysia, Jalan Gombak, 53100, Kuala \\ Lumpur, Malaysia - (zainora, norzailawati)@iium.edu.my
}

Commission VIII, WG VII/8

KEY WORDS: GIS, Hedonic Pricing Model, Public Open Space, House Price, Malaysia

\begin{abstract}
:
Presently, it is noticeable that there is a significant influence of public open space about house price, especially in many developed nations. Literature suggests the relationship between the two aspects give impact on the housing market, however not many studies undertaken in Malaysia. Thus, this research was initiated to analyse the relationship of open space and house price via the techniques of GIS-Hedonic Pricing Model. In this regards, the GIS tool indicates the pattern of the relationship between open space and house price spatially. Meanwhile, Hedonic Pricing Model demonstrates the index of the selected criteria in determining the housing price. This research is a perceptual study of 200 respondents who were the house owners of double-storey terrace houses in four townships, namely Bandar Baru Bangi, Taman Melawati, Subang Jaya and Shah Alam, in Klang Valley. The key research question is whether the relationship between open space and house price exists and the nature of its pattern and intensity. The findings indicate that there is a positive correlation between open space and house price. Correlation analysis reveals that a weak relationship (rs < 0.1 ) established between the variable of open space and house price ( $r s=0.91, N=200, p=0.2)$. Consequently, the rate of house price change is rather small. In overall, this research has achieved its research aims and thus, offers the value added in applying the GISHedonic pricing model in analysing the influence of open space to the house price in the form of spatially and textually.
\end{abstract}

\section{INTRODUCTION}

\subsection{The Context of the Study}

The significance of public open space in urbanised areas has been long recognised as they provide numerous benefits to the community in term of healthy environment as well as providing higher quality of life (Bedimo-Rung et. al., 2005; Biao, Gaodie, Bin and Canqiang, 2012). Furthermore, as indicated by BaycanLevent and Nijkamp (n.d), the benefits of green spaces have been highlighted in a more rational and convincing way by integrating the benefits into social, economic, ecological and community planning benefits. In fact, historical evidence shows urban land use planning and the urban land market are coexisted in current economic and decision-making process that eventually fluctuate the market price of housing stock. Economic arguments can help to make a decision about the trade-off between preserving environmental quality and developing housing and business surfaces, provided the benefits of environmental quality are adequately quantified.

There is an increasing awareness that urban environmental quality is highly favoured by the existence of accessible, protected and well maintained green spaces within cities, for instance, parks, green provisions, fields and others. In recent years, several urban sustainability initiatives have made a serious attempt to offer a more rigorous basis for green space planning. As a result, many initiatives and concepts such as urban planning with nature, garden city planning, brownfieldgreenfield planning, urban green networks design, urban landscape ecology, planning and so forth have been merged (Beer et. al., 2003; De Sousa, 2003; MacHarg, 1971; Jim, 2004; Pauleit, 2003; and Tjallingii, et. al.,2003).
In relation to the economic growth of the nation, it is greatly noticeable that nowadays there is a growing trend in the Malaysian housing price. However, there are not many studies undertaken to examine the relationship between the provision of open space and house price in the Malaysian context. At the international level, many studies on open space and house price were conducted with a mixed of findings, ranging from positive (see Mahan et. al., 2000; Heimlich and Anderson, 2001; Bolitzer and Netusil, 2000) and negative pattern of relationship (see Weicher and Zerbst, 1973). Contextually, Malaysia experience the loss of green space to give way to other developments, particularly in Klang Valley. This situation raises the question on on how much importance public open space to economic matters, including the factor for house pricing becomes one of the factors for implementation in planning and development decision.

\subsection{Spatial Analysis on Public Open Space and House Price}

The application of Geographical Information System (GIS) in planning the public open space is highly regarded as an essential tool to support the textual data that are qualitative in nature. By using this useful technical tool, the result could be displayed in the form of a mapping system, demonstrating the spatial relationship between open space and house price. In this regards, the Relative Importance Index (RII) technique was used to determine the relationship of the open space and house price. Kong, Yin and Nakagoshi (2007) state that in recent decades, the development of GIS has gradually made Hedonic Pricing Model (HPM) a powerful tool, but at present, it is still underutilised in urban planning research. Presently we are facing difficulty in analysing the impact of public open space to residential property value in a Malaysian scenario in which not many useful and practical tools are usable. Brasington and Hite

\footnotetext{
* Corresponding author.
} 
(2005) state that GIS can measure the environmental characteristics of properties better increasing the understanding of house pricing variations. Thus, this provides an opportunity to conduct a study and fill the gap in this research field in Malaysian context by developing and performing a GIS-HPM to understand the pattern and nature of the relationship between open space and house price. As such, the aim of this research is to analyse the relationship between open space and house price in the area of Klang Valley via the usage of GIS-HPM. As mentioned before, there is mixed evidence on the relationship between open space and house price. Some studies have observed a positive correlation, whereas others find negative or no significant effect.

\section{REVIEWS ON GIS, OPEN SPACE AND HOUSE PRICE}

\subsection{GIS application in determining house price}

The utilisation of GIS provides various benefits for real estate industry due to the capability of GIS application in recording, detecting and analysing data on the ground which contains the information needed by the real estate industry. This happens due to the fact that GIS as an interdisciplinary role of computer and spatial data analysis methods developed in varying related disciplines which involve surveying, photogrammetry, cadastral and land management, geography, soil science, environmental science, road network, remote sensing and image analysis (Qian, 2013). With a GIS-based information system, a lot of information can be displayed on maps and helps parties involved in the real estate industry such as realtors, buyers, sellers and developers in making the decision about searching suitable properties to be bought/developed or estimating market values.

GIS technologies, in fact, have the analytical capabilities needed for calculating a spatial distribution of the factors of land value, thus useful in determining housing price for a particular study area (Azar et. al., 1994). Several important elements which have to be considered are the boundary for spatial data involved in the study. It is easier to determine housing boundaries as the boundaries are commonly have been recorded by lot boundaries in the data for the particular neighbourhood which originally comes from several pieces of developed lands. On the other hand, it is essential to determine the boundaries of open space existed within the neighbourhood as the size and proximity of green spaces to the house locations are needed to include green space as one of the factors in house pricing. The key factors in house pricing have to be keyed in the particular formula for the software to analyse and calculate the results which resemble the figures that can be considered as final prices.

\subsection{Public Open Space as an Environmental Goods}

The development of environmental awareness has resulted in strong demand by urban residents for green space/open space for various purposes, including aesthetic enjoyment, recreation, and access to clean air or a relatively quiet environment (Miller, 1997; Tyrvainen and Miettinen, 2000). Miller (1997), More et. al. (1988) and Tyrvainen and Vaananen (1998) say that amenity values attached to urban open spaces are considered as the nonmarket price to the environmental benefits that cannot be directly traded on an open market. Such conflicting trends raise the need for green space protection and allocation, which in turn requires estimates of the recreational value of green spaces.
The determination of the value to society of such non-market priced recreation resources is not a new concept to environmentalist and economists. The trend in the housing market shows that the contingent valuation method is the most prevalent method used to estimate an economic value for environmental goods. The global environmental movement has led to the recognition of open space as significant environmental goods to enhance the quality of life of urban dwellers. Though the effect of open space as environmental goods is not high enough, its provision within residential areas is given emphasis by the government.

\subsection{Factors contribute to the quality of open space}

Apart from the planning consideration taking into account in providing open spaces, the community also regards the management aspect as essential to have a good quality of open space. Good quality and aesthetics are known to be the factors that influence perceptions on open spaces (Van Herzele and Wiedemann, 2003; Giles-Corti et. al., 2005). Literature suggests several management factors can make the provision of open space at satisfactory acceptance of the community, ranging from the strategic locational factor, the adequate size of open space, the condition of the facilities provided, regular maintenance, the level of cleanliness and so forth.

\subsubsection{Good location and proximity}

The location of open space within a neighbourhood determines its accessibility and proximity perceived by the surrounding residents (Koohsari et. al., 2013). Nyaupane (2011) states that distance to parks and open space influenced only perceived personal and social benefits. This opinion is relevant as walking to the nearest open spaces is a personal choice of the users. A study by Donnelly (2005) found that homes near open space will be more expensive than homes at a distance, considering that all other housing attributes are equal. This opinion is supported by Burton and Hicks (1996) and Dehring and Dunse (2006) on the effect of proximity to public open space in Aberdeen, Scotland.

\subsubsection{Adequate Size, Hierarchy and Catchment Area}

The size of open space could be a factor to ensure that users' needs are met adequately, preferably an open and coherent area which is adaptable to change (Nilsen and Hägerhäll, 2012), either passive or active recreation (Thompson, 2002). The concept of a hierarchy of open space has been initially viewed that open space needs to be organised in the hierarchical fashion based on spaces within regional and neighbourhood areas (Harnic \& Simms, 2004). Meanwhile, Pollard (2003) suggests that various scales of public open space are required which include large and regional parks that protect and offer access to natural areas as well as provide access to a range of activities; and smaller parks within the neighbourhood areas which are located within walking distance for most residences. Different scales of open space are categorised under different hierarchies with a different catchment area of users (Cohen et. al., 2009).

\subsubsection{Good Provision of Facilities}

The provision of adequate and suitable facilities is vital for open space to create a functional and user-friendly environment within the open space. The provisions of appropriate and functioning facilities are also necessary for the security of the users such as the provision of adequate lighting and surveillance system. Nyaupane (2011) recommended that parks and public land management agencies should educate citizens concerning the amenities and opportunities offered to extend the public 
interest in outdoor recreational activities. Open space should attempt to cater for multiple users through landscaping and the provision of facilities. Thus, it will be able to provide various walks of life (Giles-Corti et al., 2005).

\subsubsection{Regular Maintenance and Cleanliness}

Sunarja et. al. (2008) suggest that open space should be well maintained and actively managed while Lindgren and Castell (2008) and (Lindgren, 2010) noted that the management approach might be necessary for maintaining open space helps for the open space to be 'well-kept'. The aspects of open space maintenance cover several aspects including performed inhouse or by a contractor, carried out by local manager or circulating teams and the residents who are involved in the management. Thompson (2002) argues that the maintenance of open space is vital to ensure that it can reach the optimum level of use and targeted user groups. This statement reflects the fact that open spaces do not consist of $100 \%$ natural environment and need efficient management and maintenance. Regular maintenance helps in maintaining the facilities and cleanliness within the open spaces.

Various micro factors are influencing the house price which refers to a branch of economics that analyses the market behaviour of individual consumers at a local level. It is concerned with the interaction between individual users and its ambient surroundings that influence the choices made by them. In this context, among the examples of micro factors involve are the house design, its location and the availability of public facilities within the area.

\section{RESEARCH METHODOLOGY}

\subsection{Questionnaire Survey}

The approach adopted in conducting the 'structured and closeended' questionnaire survey is a sample survey in which its objective is to arrive at subjective inferences about the population in the selected sites based on the information supplied from the sample 200 population. Therefore, the targeted population selected encompassed by those reside in Taman Melawati, Subang Jaya, Bandar Baru Bangi and Shah Alam within the areas of Klang Valley (Figures 1,2,3 and 4). All these townships were selected based on the following criteria:

i. had been established for more than ten years;

ii. had been developed by Prestige developers;

iii. the areas have a high density of population;

iv. located within highly urbanised areas, and

v. the availability of open space within the sites.

The questionnaire form was divided into three sections: backgrounds of respondents; information on the house; and factors influence the house price. From the survey conducted, the study could derive the understanding pattern of house ownership and the identification of the preferred elements of open space and the prioritisation of the main factors related to the provision of public open space.

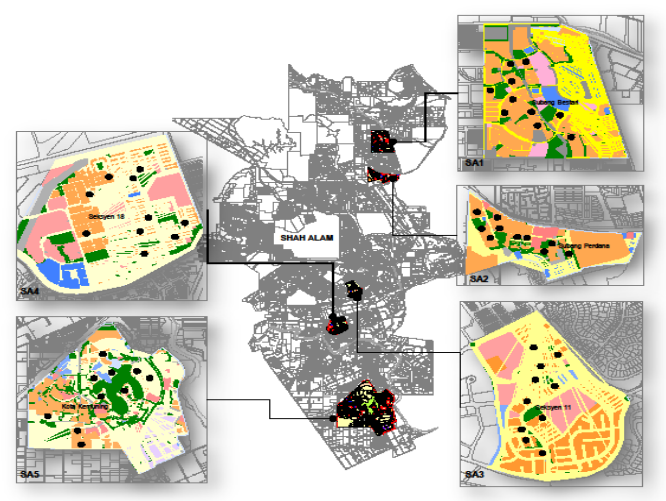

Figure 1: Township of Shah Alam

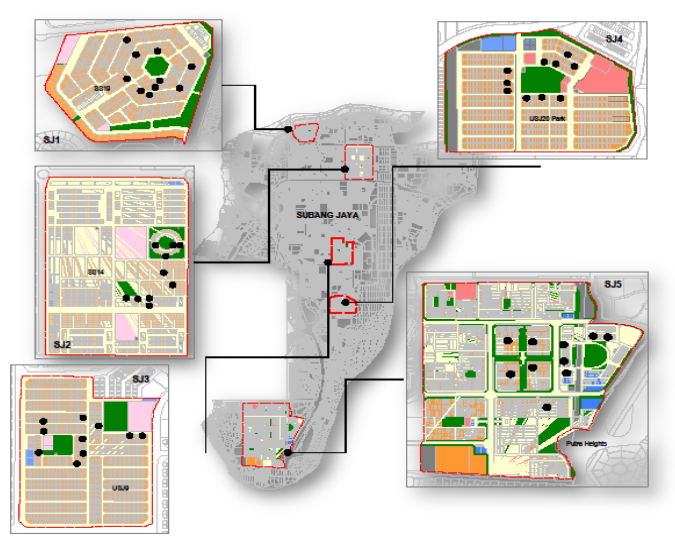

Figure 2: Township of Subang Jaya

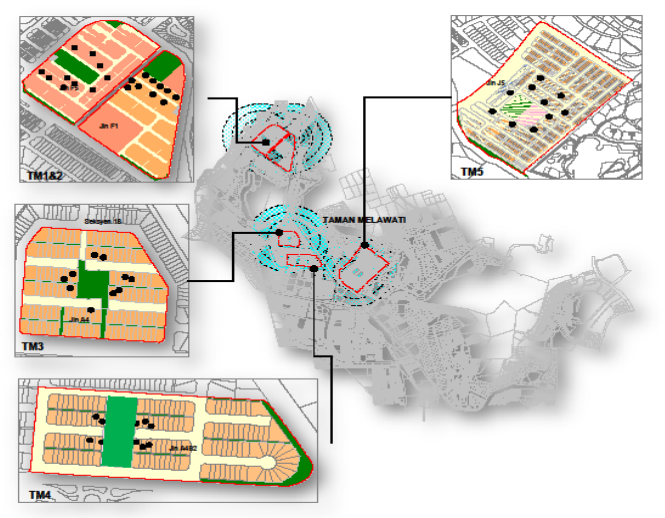

Figure 3: Township of Taman Melawati

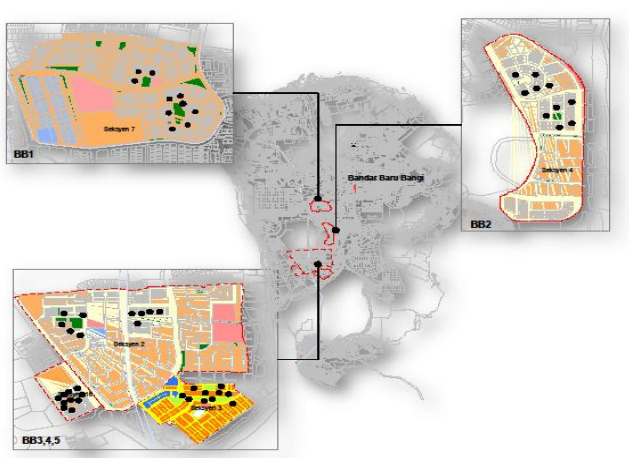

Figure 4: Township of Bandar Baru Bangi 
Each site has been divided into five survey parcels that had been labelled with sequence numbers based on each township. For the convenient purpose, 50 respondents were selected from each survey plot representing their residential areas based on the distance to the open space. For instance, TM1 has selected ten respondents based on the spatial distribution of setback of open space and their houses, i.e. $50 \mathrm{~m}, 150 \mathrm{~m}$ and $400 \mathrm{~m}$. This approach is necessary to indicate the spatial relationship between the location of open space and the feedback given by the respondents which later to be shown using GIS technique.

\subsection{GIS-Hedonic Pricing Model}

This study employed two types of analysis, namely network and spatial analysis. For the network analysis, the accessibility of the public open space was measured by using Space Syntax or GIS Network Analysis techniques. The Network Analysis technique was relied on distance measurement between the open space and the distance of housing unit. Meanwhile, the space syntax technique evaluated the spatial configuration of the open space.

Space syntax is a methodology for representing the morphology of buildings, open spaces and streets. Space syntax models the spatial configurations of urban spaces by using a connectivity graph representation. Jiang and Claramunt (2002) believe that space syntax provides a configurational description of an urban structure and attempts to explain human behaviour and social activities from a spatial configuration point of view. The syntactic measure of accessibility is regarded as a geometric accessibility measure (Jiang and Liu, 2010). There is a growing debate on which approach is more dependable in measuring accessibility (Steadman, 2004). Meanwhile, for spatial analysis that relates to the buffer analysis is a vector-based proximity analysis, which is carried out in ArcGIS 10.1. It creates buffer polygons to a spatial distance around the input features used following standards of buffer distance for this study.

In the process of capturing the data on the influence of proximity to open space to house price, the buffer distance values as an attribute are shown in the open space layer. Then the buffer analysis was performed and the service area polygons were produced. The intersect process of this dissolved layer with the ward boundary of the study area was prepared to get the wise ward distribution of service area. The same procedure was applied for each category of data (Figure 5).

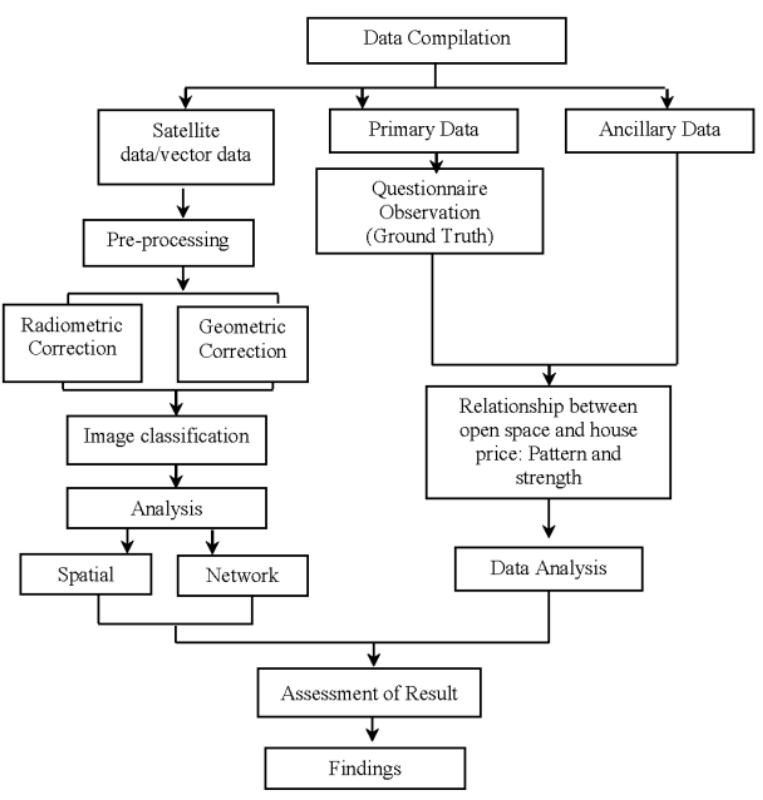

Figure 5: Flowchart of GIS methodology

Over the last two decades, many researchers applied HPM when analysing their work that relates to environmental goods and environmental economics such as Garrod and Willis (1992), Hunt, Boxall, Englin, \& Haider (2005) and Morancho (2003). HPM is a method for decomposing a commodity into its constituent characteristics and estimating their implicit prices. Moreover, this approach is an indispensable tool in the study of real estate markets. HPM is widely applied in developed countries to assess the value of nature associated with settlements. Besides that, this method can be used in several fields such as estimating demand for housing and neighbourhood attributes, making general improvements in house price indices, analysing the impact of neighbourhood externalities; measuring housing needs in residential mobility studies; appraising individual homes and examining the capitalisation of a wide range of amenities. One of the biggest challenges in the discipline of environmental and natural resource economics is to measure the monetary value of or willing to pay (WTP) for natural resource and environmental amenities because they are non-market goods. Therefore, the HPM has preferred method to quantify WTP from a market commodity purchased that is correlated with environmental and natural resource amenities of interest. The emergence of GIS technology and the progress in the fields of spatial econometric and statistic assist in bringing hedonic analysis into a new domain. Using a GIS-supported spatially explicit approach in the HPM could also help in targeting specific locations for the construction of urban open space. In addition, of HPM, it can model the house price as a function of different attributes to derive the marginal implicit price of the attribute, which reflects a value that homeowners place on an attribute. The awareness of many researchers to a major limitation of the traditional hedonic analysis, namely its insensitivity to the spatially of housing datasets, and of the potential consequences of omitting spatial effects on the statistical validity and reliability of models, has led to a different understanding and emphasis of price determination processes.

Housing is a multi-attribute commodity, accessibility to work, transport and amenities, and its neighbouring properties are routinely considered by housing buyers. The previous study 
consistently demonstrated that a value of urban green had a 5\%$20 \%$ premium on neighbouring property values. An overall questionnaire area interviewed about the profile of housing ownership, including the length of staying and prices while they purchased that property. In this study, the hedonic price method is used to measure the relative importance- through the use of regression analyses of variables on house and property prices and the price of a house can be summarised using a primary hedonic price function as below (Kong, Yin and Nakagoshi, 2007):

$$
P=f\left(\mathrm{x}_{1}, \mathrm{x}_{2}, \ldots \ldots \ldots \mathrm{x}_{n}\right)
$$

Where $\mathrm{P}$ is the market price of the housing and $\mathrm{x} 1$, $\mathrm{x} 2, \ldots \ldots \ldots \mathrm{xn}$ are the characteristic contained in the property. The average house price of per residential district as the housing price $(\mathrm{P})$; location (LST), size (ADS), hierarchy (HCU), facilities (FSSU), maintenance (RM) and cleanliness (CWK). This study performed RII in SPSS software to reveal the effect radius of different parks. Four limits with a range of $100 \mathrm{~m}$ to 400 metre for each ring have been applied in this study, reflecting the acceptable maximum radius 400 metres for a standard walking distance in tropical country like Malaysia.

\section{RESEARCH FINDINGS}

\subsection{Prioritising elements of open space}

Respondents were asked about their perception of the importance of open spaces concerning determine the offered house price within their residential areas. This research used RII as the technique to set the priority of the importance level of elements of open space from the perceptions of the house owners. The results shown in Table 1 indicate the level of importance of elements of open space perceived by the users/house owners. In the context of Malaysian urbanised areas, the results demonstrate that the key element of open space opted by the community is the aspect of cleanliness whereby its RII is 0.894 . The users are looking for a well-kept open space that is free of the following problems: broken playground equipment, animal waste, graffiti, messy with litter, cracked concrete, overfull rubbish bins, missing nets, and uneven playing surfaces.

The other element that has a strong association with the element of cleanliness is the regular maintenance of the open space (RII is 0.882 ). Of the six pre-determined elements, the planning aspect, i.e. location and size were at the 4 th and 5th place respectively. It seems that the respondents did not regard the planning aspect of open space as a key influential factor in determining house price. They put the importance on the management aspect of the provision of open space, i.e. they would like the areas to be kept clean with good maintenance and adequate facilities. Based on the perspective of the respondents, it seems that the provision of open space has conformed to the planning requirement. Consequently, they preferred to have the proper management of the open space for sustainable use of their family members. A study by BedimoRung, Mowen and Cohen (2005) in the USA demonstrates the importance of the management aspect of open space is highly regarded by the users.

\begin{tabular}{|c|c|c|c|c|c|c|}
\hline Elements of Open Space & 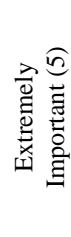 & 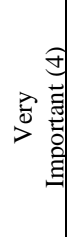 & 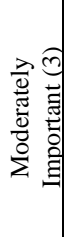 & 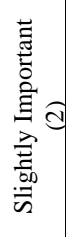 & 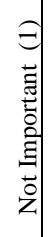 & 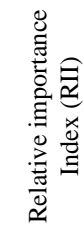 \\
\hline \multicolumn{7}{|c|}{ Management aspect } \\
\hline $\begin{array}{l}\text { 1. Cleanliness is well kept } \\
\text { (CWK) }\end{array}$ & 114 & 68 & 16 & 2 & 0 & 0.894 \\
\hline $\begin{array}{l}\text { 2. It has regular } \\
\text { maintenance (RM) }\end{array}$ & 100 & 84 & 14 & 2 & 0 & 0.882 \\
\hline $\begin{array}{l}\text { 3. The facilities provided } \\
\text { are sufficient and } \\
\text { suitable to the users } \\
\text { (FSSU) }\end{array}$ & 89 & 93 & 16 & 1 & 1 & 0.868 \\
\hline \multicolumn{7}{|c|}{ Planning aspect } \\
\hline $\begin{array}{l}\text { 4. The location is strategic } \\
\text { (LST) }\end{array}$ & 76 & 98 & 23 & 2 & 1 & 0.846 \\
\hline $\begin{array}{l}\text { 5. The size is adequate } \\
\text { (ADS) }\end{array}$ & 67 & $\begin{array}{c}10 \\
3\end{array}$ & 25 & 3 & 2 & 0.830 \\
\hline $\begin{array}{l}\text { 6. The hierarchy fulfils the } \\
\text { catchment area of users } \\
\text { (HCU) }\end{array}$ & 55 & 84 & 53 & 5 & 3 & 0.783 \\
\hline
\end{tabular}

Table 1: The importance of elements of open space

The literature mentions there is much robust and valid evidence indicating the property enhancement value of open space in many places. In developed nations, their community considers high value on the existence of open space with which they regard it as an influential factor determining the enhancement of property value. Unfortunately, the results of Klang Valley did not show the same pattern. Indeed, some local factors influence this kind of results, such as the level of appreciation of the open space as environmental goods are low, the cultural background and so forth. The relationship between the existence of open space with the offered price was conducted using a Spearman correlation analysis. The results from the correlation analysis revealed ( $\mathrm{rs}=0.091, \mathrm{~N}=200, \mathrm{p}=0.2$ ) that is a weak relationship (rs $<0.1$ ) between these two variables (Table 2 ). The result suggests that there is a low concern within respondents on the existence of open space in term of deciding to offer price if they plan to sell their houses.

\begin{tabular}{|c|c|c|c|}
\hline \multicolumn{2}{|c|}{ Spearman's Rho } & $\begin{array}{c}\text { Will the } \\
\text { existence of } \\
\text { open space to } \\
\text { increase the } \\
\text { price of your } \\
\text { house? }\end{array}$ & $\begin{array}{c}\text { Offered } \\
\text { price of } \\
\text { house } \\
\text { (if plan to } \\
\text { sell) }\end{array}$ \\
\hline \multirow[t]{3}{*}{$\begin{array}{l}\text { Will the existence of } \\
\text { open space to } \\
\text { increase the price of } \\
\text { your house? }\end{array}$} & $\begin{array}{l}\text { Correlation } \\
\text { Coefficient }\end{array}$ & 1.000 & .091 \\
\hline & Sig. (2-tailed) & & .199 \\
\hline & $\mathrm{N}$ & 200 & 200 \\
\hline \multirow{2}{*}{$\begin{array}{l}\text { The offered price of } \\
\text { a house (if plan to } \\
\text { sell) }\end{array}$} & $\begin{array}{l}\text { Correlation } \\
\text { Coefficient }\end{array}$ & .091 & 1.000 \\
\hline & $\begin{array}{c}\text { Sig. (2-tailed) } \\
N\end{array}$ & $\begin{array}{l}.199 \\
200\end{array}$ & 200 \\
\hline
\end{tabular}

Table 2: Correlation between existence of open space and offered price

The research also examines the relationship between the strategic location of open space and house price. The results derived by using a Pearson correlation analysis and again, it 
produced a weak correlation $(\mathrm{rs}=0.14, \mathrm{~N}=200, \mathrm{p}=0.48)$ (Table 3). The Higher importance of the strategic location of open space was associated with higher offered price. However, there is the low concern on strategic location when deciding an offered price for this case. This result shows the scenario of the relationship between the aspect of location (planning factor) and the probable price from the perspective of the selected respondents.

\begin{tabular}{|cc|c|c|}
\hline \multicolumn{2}{|c|}{ Spearman's Rho } & $\begin{array}{c}\text { The } \\
\text { location is } \\
\text { strategic }\end{array}$ & $\begin{array}{c}\text { Offered } \\
\text { price of } \\
\text { house } \\
\text { (if plan to } \\
\text { sell) }\end{array}$ \\
\hline $\begin{array}{c}\text { The location is } \\
\text { strategic }\end{array}$ & $\begin{array}{c}\text { Pearson } \\
\text { Correlation } \\
\text { Sig. (2-tailed) } \\
\text { N }\end{array}$ & 1 & $.140^{*}$ \\
$\begin{array}{c}\text { Offered price of } \\
\text { house } \\
\text { (if plan to sell) }\end{array}$ & $\begin{array}{c}\text { Pearson } \\
\text { Correlation }\end{array}$ & $.140^{*}$ & .048 \\
& Sig. (2-tailed) & .048 & 200 \\
$\mathrm{~N}$ & 200 & 200 \\
\hline
\end{tabular}

* Correlation is significant at the 0.05level (2-tailed).

Table 3: Correlation between strategic location of open space and offered house price

\subsection{The Influence of Open Space to House Price}

Based on the outcome, the results indicate that the possible monetary value will be increased using the universal approach of GIS spatial analysis. Four rings with a radius of 400meters and range of 100meter each, the estimated value of the house price will be increased by $3 \%-12 \%$ (JPPH, 2014). The neighbourhood park with an area of more than 2 hectares was used to be nodes and result found that in each range of $100 \mathrm{~m}$ to open space, the prices will be increased by $3 \%$. These processes have been applied in ArcGIS 10.1 software using the buffer analysis.

This result shows that based on open space size (neighbourhood park), the possibilities of increasing in house prices are at the rate of $3-12 \%$, which is slightly lower than the international perspectives. The justification of this percentage has been based on the annual increment on house price in Malaysia, particularly in Selangor, where the four townships are located. The rapid development and infrastructure provided in these areas have become the catalyst to attract the prospect buyers.

These research findings could provide useful insights and hints for both real-estate developers and the government. GIS-HPM techniques could help to refine the art and science of property valuation. It adds a new dimension to the study of related issues in Malaysia, including property purchase and sale, transfer, tax assessment, investment and financing. Decision makers could apply the method to make an informed weighing of alternatives in land acquisition for residential development. The analysis could help judgement on marketability and potential profit margin. It could enlighten decision on whether to purchase a piece of expensive land situated in a densely urbanised area with limited room for open spaces, or a piece of cheaper rural land with similar open space rooms plus good external environment. The determination of the sale prices of individual units could more accurately take into account people's preference and desire to have a view or access to open spaces and other environmental amenities. The urban planner could be moulded to improve and apply the strict policies to strengthen enforcement in providing $10 \%$ open spaces in development proposal; it should tally with supplies to meet consumer demands and to raise the value of the development.

The Town and Country Planning Department (TCPD) could use the method to inform land use zoning, especially to find an appropriate location for open spaces. It could provide objective data to develop a nature conservation plan and open space plan for the city to preserve natural areas of high ecological value to upgrade existing, and to provide new ones based on landscape ecology principles. The $10 \%$ of open spaces comply with planning permission nowadays are no longer adopted when the urbanisation process happened. The government should think to plan a sustainable development whereby most of the green area has been preserved and provided to the residents. However, a constraint in local governments was the budget to protect open spaces in urban areas is often insufficient. Land rent is collected by local governments when developers use the land for buildings and often land price determination is inordinately affected by political and administrative factors. Local government revenue from land rent could be correctly estimated especially when a piece of land is attached close to open spaces and areas of high ecological or scenic quality. The quality outlook for this study could aim at expanding studies in different categories of housing with varying variables of factors that influence a house price in Malaysia. Since last five years back, the housing prices in Malaysia are rigorously increased, therefore, to advocate quality of life through urban greening, the GIS-HPM could yield research finding that lends support to the people in attributing an environmental value in the home purchase decision.

Since urban open space has a positive impact on proximate property value, this represents a "capitalisation" of park land into increased property values of proximate landowners. Urban regeneration process which happened in all cities in Malaysia was aiming for better and positive results, but it is not simple to carry out this process without understanding its impact on an area more importantly to the people who live there. It was a comprehensive and integrated vision and action which leads the resolution of urban problems and which seeks to bring about a lasting improvement in the economic, physical, social and environmental condition of an area that has been subject to change. The role and value of open spaces in the urban regeneration process should be established through the enforcement and implementation compliance by decision makers. In this research, the approach of integration GIS-HPM was analysed in determining values of open spaces in housing prices.

\section{CONCLUSION}

The HPM is a useful aid or guide to understanding the amenity value of urban open space. The modelling results could be used to inform policy decisions concerning urban open space preservation and allocation. Inserting urban open spaces in undeveloped areas before they are subject to development pressures will reduce leapfrogging development in or around the preserved scenery forest or other open space areas. In addition to assessing open space value, analysis regarding the amenity impact of spatial land use patterns could also contribute to policy analysis and design, particularly in assisting in the targeting of detailed district planning. Using a GIS-supported spatially explicit approach in the hedonic model could also help 
in targeting specific locations for the construction of urban open space.

This study also applied GIS techniques of Klang Valley open spaces to measure the impact our residential on property value. This study not only provides a better understanding of the relationship between house prices and open spaces in Klang Valley but it also a new perspective on investment strategy on urban open spaces for the city policy makers. This study shows that the environmental dimension plays a significant role in the spatial structure of residential house prices. Moreover, the significance of interactive variables shows that the consideration of combined influences is useful for a better understanding of the residential market. Although only parts of the environmental amenities are integrated, the effect of the residual on spatial autocorrelation is very significant.

\section{References}

\section{References from Journals:}

Bedimo-Rung, L.A., Mowen, A.J., \& Cohen, D.A. 2005. The significance of parks to physical activity and public health: A conceptual model. American Journal of Preventive Medicine, 28(2S2), pp. 159-168.

Beer, A.R., Delshammar, T., \& Scildwacht, P. 2003. A changing understanding of the role of green space in highdensity housing: A European perspective. Built Environment, 29(2), pp. 132-143.

Biao, Z., Gaodia, X., Bon, X., and Canqiang, Z. 2012. The effects of public green spaces on residential property value in Beijing. Journal of Resources and Ecology, 3 (3), pp. 243-252.

Bolitzer, B., \& Netusil, N. 2000. The impact of open space on property values in Portland, Oregon. Journal of Environmental Management, 59. pp. 185-193.

Brasington, D.M., \& Hite, D. 2000. Demand for environmental quality: A spatial hedonic analysis. Regional Science and Urban Economics, 35(1), pp. 57-82.

Cohen, D., Sehgal, A., Williamson, S., Marsh, T., Golinelli, D. $\&$ McKenzie, T. 2009. New recreational facilities for the young and the old in Los Angeles: 62 policy and programming implications, Journal of Public Health Policy, 30(1), pp. 248263.

Dehring, C. and Dunse, N. 2006. Housing density and the effect of proximity of public open space in Aberdeen, Scotland. Real Estate Economics, 34(4), pp. 553-556.

De Sousa, C.A. (2003). Turning brownfields into green space in the city of Toronto. Landscape and Urban Planning, 62, pp. 181-198.

Garrod, G. \& Willis, K., 1992. The environmental economic impact of woodland: a two-stage hedonic price model of amenity value of forestry. Britain.Appl. Econ. 24, pp. 715-728.

Giles-Corti, B., Broomhall, M.H., Knuiman, M., Collins, C., Douglas, K., Ng, K., Lange, A., \& Donovan, R.J., 2005. IncreasingWalking: how Important is Distance to,
Attractiveness, and Size of Public Open Space? American Journal of Preventive Medicine, 28, pp. 169-176.

Harnic, P. \& Simms, J. 2004. Parks: how far is too far. Journal of American Planning Association. 70, pp. 8-11.

Hunt, L.M., Boxall, P., Englin, J., Haider, W., 2005. Remote tourism and forest management: a spatial hedonic analysis. Ecol. Econ. 53, pp. 101-113.

Jiang B. \& Claramunt C. 2002. Integration of space syntax into GIS: new perspectives for urban morphology, Transactions in GIS, 6(3), pp. 295-309.

Jiang B. \& Liu, X. 2010. Automatic generation of the axial lines of urban environments to capture what we perceive, International Journal of Geographical Information Science, 24(4), pp. 545-558.

Jim, C.Y. 2004. Green space preservation and allocation for sustainable greening of compact cities. Cities, 21(4), pp. 311320 .

Koohsari, M.J., Kaczynski, A.T., Giles-Corti, B. \& Karakiewicz, J.A. 2013. Effects of access to public open spaces on walking: is proximity enough? Journal of Landscape and Urban Planning, 117, pp. 92-99.

Kong, F., Yin, H. \& Nakagoshi, N. 2007. Using GIS and landscape metrics in the hedonic price modeling of the amenity value of urban green space: A case study in Jinan City, China. Journal of Landscape and Urban Planning. 79, pp. 240-252.

Lindgren, T. 2010. Justice as a principle for the distribution of open space maintenance: the conception of housing staff and tenants. Journal of Housing and the Built Environment, Vol. 26, 1, pp. 17-32.

Lindgren, T. \& Castell, P. 2008. "Open space management in residential areas - how it is organized and why", International journal of Strategic Property Management, Vol. 12 No. 3, pp. 141-60.

Mahan, B.L., Polasky, S., \& Adams, R. M. 2000. Valuation urban wetlands: A property approach. Land Economics, 76(1), pp. 100-113.

Morancho, A.B., 2003. A hedonic valuation of urban green areas. Journal of Landscape and Urban Planning. 66, pp. 3541.

More, T.A., Stevens, T., \& Allen, P. G. 1988. Valuation of urban parks. Journal of Landscape and Urban Planning, 15, pp. 139-152.

Nilsen, A. H. \& Hägerhäll, C. M. 2012. Impact of space requirements on outdoor play areas in public kindergartens. Nordic Journal of Architectural Research, 24(2), pp. 8-28.

Nyaupane, G. P. 2011. Benefits of open space: Managers' and local residents' perspectives. Journal of Park and Recreation Administration. 29 (4), pp. 20-36. 
Pauleit, S. 2003. Perspective on urban green space in Europe. Built Environment, 29(2), pp. 89-93.

Pollard, T. 2003. Policy prescriptions for healthier communities. American Journal of Health Promotion, 18/1, pp. 109-113.

Qian, R. (2013. The application of GIS in the real estate management system. Advances in Intelligent Systems and Computing, 191, pp. 553-558.

Steadman P. 2004. Developments in space syntax. Environment and Planning B: Planning and Design, 31, pp. $483-486$.

Thompson, W.C. 2002. Urban open space in the 21st century, Journal of Landscape and Urban Planning, 60, pp. 59-72.

Tjallingii, S., Green \& Red. 2003. Enemies or allies? The Utrecht experience with green structure planning. Built Environment, 29(2), pp. 107-116.

Tyrvainen, L., \& Miettinen, A. 2000. Property prices and urban forest amenities. Journal of Environmental Economics and Management, 39(2), pp. 205-223.

Tyrvainen, L., \& Vaananen, H. 1998. The economic value of urban forest amenities: $\mathrm{n}$ applicatiaon of the contingent valuation methods. Journal of Landscape and Urban Planning, 43, pp. 105-118.

Van Herzele, A., \& Wiedemann, T. 2003. A monitoring tool for the provision of accessible and attractive urban green spaces. Journal of Landscape and Urban Planning, 63, pp. 109-126.

Weicher, J.C., \& R.H. Zerbst 1973. The externalities of neighbourhood parks: An empirical investigation. Land Economics, 49(1), pp. 105-112.

\section{References from Books:}

MacHarg, I. L. 1971. Design with Nature. Garden City, New York: Doubleday.

Miller, R. W. 1997. Urban Forestry: Planning and Managing Urban Green Spaces (2nd ed.). Englewood Cliffs, New Jersey: Prentice-Hall.

Roberts, P. \& Sykes, H. 2000. Urban regeneration: a handbook. London: British Urban Regeneration Association.

\section{References from Other Literature:}

Azar, K.T., Ferreira, J., Abed, J., \& Kazzaz, T. 1994. Using GIS for estimating the spatial distribution of land value in metropolitan Beirut. URISA.

Baycan Levenet, T., \& Nijkamp, P. n.d. Critical Success Factors in Planning and Management of Urban Green Space in Europe. Free University Amsterdam, Faculty of Economics Sciences, Business Administration and Economitrics.

Burton, M.L. and Hicks, M.J. 2003. Public parks, housing values and fiscal flexibility.
Donnelly, M. 2005. Measuring the value of open space: a hedonic study.

Heimlich, R. \& W. Anderson. 2001. Development at the Urban Fringe and Beyond: Impacts on Agriculture and Rural Land. Agricultural Economics Report No. 803. Washington, D.C.: USDA Economic Research Service.

JPPH, (2014). Laporan Indeks Harga Rumah Malaysia 2014. Kuala Lumpur: Jabatan Penilaian dan Perkhidmatan Harta.

Sunarja A, Wood G \& Giles-Corti B. 2008. A fact sheet on healthy public open space design for multi-users and multiuses, The Centre for the Built Environment and Health, University of Western Australia.

\section{ACKNOWLEDGEMENTS}

The researchers would like to express their thanks to the Institute of National Valuation (INSPEN) and Research Management Centre (SP13-054-0122) of International Islamic University Malaysia (IIUM). The opinions expressed herein are those of the researchers and do not necessarily reflect the views of the funder and the university. 